An integrated lean and ISO 14001 framework for environmental performance: an assessment of New Zealand meat industry

\begin{tabular}{|r|l|}
\hline Journal: & International Journal of Lean Six Sigma \\
\hline Manuscript ID & IJLSS-05-2021-0100.R1 \\
\hline Manuscript Type: & Research Paper \\
\hline Keywords: & Lean, ISO 14001, integration, conceptual framework, meat industry \\
\hline \multicolumn{2}{|r}{} \\
\hline
\end{tabular}




\title{
An integrated lean and ISO 14001 framework for environmental performance: an assessment of New Zealand meat industry
}

\begin{abstract}
Purpose -The aim of this paper is to explore the implementation of an integrated lean and ISO 14001 approach in meat industry for environmental performance and examine a proposed conceptual framework by capturing insights from lean and ISO 14001 experts in New Zealand (NZ).
\end{abstract}

Design/methodology/approach - Semi-structured interviews have been conducted with a group of consultants (lean and ISO 14001) to evaluate the suitability of an integrated lean and ISO 14001 approach in the meat industry for environmental performance. A conceptual framework from literature has guided this study leading to its further development based on the empirical evidence collected.

Findings - Findings have illustrated a synergistic positive impact of lean and ISO 14001 implementation as an integrated approach for sustaining environmental performance in the meat industry. A joint implementation programme provides more clarity in aligning ISO 14001 operational procedures with lean tools and techniques for an enhanced environmental performance outcome.

Practical implications - The application of an integrated lean and ISO 14001 framework is proposed in this paper, which can help industry practitioners and academia in developing a joint implementation strategy and conducting future research.

Originality/value - To the best of author's knowledge, this study is the first to assess the effective implementation of lean and ISO 14001 as an integrated approach in the NZ meat industry.

Keywords Lean, ISO 14001, integration, conceptual framework and meat industry.

Paper type Research paper

\section{Introduction}

Upsurge in meat consumption as a result of rapid growth in the world's population has led to an increase in meat processing in recent years. New Zealand (NZ) is considered amongst one of the big exporters of meat products globally. Currently, NZ exports beef (428,245 tonnes), lamb (378,247 tonnes) and poultry products (201,040 tonnes) worldwide (Carson and East, 2018). Although there has been a rapid growth in meat processing, this sector is considered as the biggest contributor of pollutants in the food industry as it generates abundant wastewater (cleaning agent, blood, manure and dirt) solid waste (head, legs, fat, hairs, offal and skin) and consumes excessive energy (cooling treatments and heat) (Djekic et al., 2016). Many different types of air pollutants (sulphur oxides, nitrogen oxides and carbon dioxides) are produced in the meat processing facilities due to excessive utilization of raw materials and ineffective waste control systems (Roy et al., 2012).

Since the start of $1980 \mathrm{~s}$, environmental waste management and effective utilization of resources (raw materials and energy consumption) are treated as an integral part of strategy and policy deployment after the introduction of lean implementations in the manufacturing industry (Campos et al., 2015). Lean Six Sigma (LSS) is an approach that can enhance and sustain the performance of a company by eliminating waste and reducing process variation (Parmar and Desai, 2019). LSS is employed as a methodology for maximizing stakeholder value, increasing process performance, and enhancing customer satisfaction (Antony et al., 2019; Muraliraj et al., 2018; Parmar and Desai, 2019). Lean practices improve operational and environmental performance by reducing waste, enhancing process efficiencies, optimizing operational capabilities, and effectively utilizing resources (Dieste et al., 2020; Farrukh et al., 2020; Garza-Reyes et al., 2018) whereas six sigma focuses on reduction of variations and 
improvement of processes (Ali et al., 2020). The application of lean and six sigma components within a LSS project depends on the scope of the LSS project (Muraliraj et al., 2018). Some LSS projects would be significantly front loaded with lean practices to exploit, metaphorically speaking, the "low hanging fruit" (ISixSigma, 2021). Lean, due to its focus on improving efficiencies and waste elimination, is adopted extensively by businesses for achieving effectiveness in operations and satisfying customers, with a positive impact on environmental performance (Ali et al., 2020; King and Lenox, 2001).

Many manufacturing firms have also implemented ISO 14001, which is not only utilized as a base standard for obtaining ISO certification and providing guidelines in formulating an environmental management system (EMS) to conduct environmental audits (Fortuński, 2008), but also for sustaining environmental performance (Arimura et al., 2016; Wong et al., 2017). An integrated implementation of ISO 14001 and lean manufacturing in the meat processing industry can work as an effective improvement initiative for enhancing environmental performance. ISO 14001 is a systematic approach for environment performance improvement based on internal management procedures and provides a framework for environmental performance evaluation (Arimura et al., 2016; Habidin et al., 2018). Whereas, lean is a process improvement strategy that can be used to reduce water consumption, optimize natural resource utilization, and reduce different forms of wastes (solids and emissions of greenhouse gases) (Simon and Zokaei, 2005; Verrier et al., 2014). In a recent study, Chen et al. (2020) emphasized the need to conduct research that integrate lean and ISO 14001 implementation to leverage synergies of both strategies in improving environmental performance. Deming's plan-docheck-act (PDCA) cycle is the main operating principle in implementing both, lean (Aguado et al., 2013) and ISO 14001 (Sartor et al., 2019) for sustaining continual operational and environmental performance. Development of a comprehensive framework to establish the correlation and integration between lean and ISO 14001 for environmental process improvement could be considered as a future strategy for sustainability. Very few attempts have been made to integrate ISO 14001 and lean tools/techniques (Habidin et al., 2018; Puvanasvaran et al., 2014) and the present literature lacks in assessing the potential synergies or conflicts in their integration. There is an acute need for an integrated concept that could be implemented where both lean and ISO 14001 implementation strategies are considered together for improving environmental processes (Chen et al., 2020).

Therefore, the primary objective of this paper is to gain insights from experienced lean and ISO 14001 consultants: to explore the implementation of an integrated lean and ISO 14001 approach in the meat industry for environmental performance and examine suitability of a proposed conceptual framework for this process.

Recently, an integrated lean and ISO 14001 conceptual framework for environmental performance has been proposed by Ahmed and Mathrani (2019) based on literature review, using the PDCA cycle to elucidate an environmental management programme. This framework is utilized for collecting empirical evidence from NZ based meat industry to validate the application of lean and ISO 14001 implementation as a combined approach for environmental performance. Using a qualitative approach, primary data are collected by conducting six semistructured interviews with lean and ISO 14001 consultants to better understand the use of an integrated lean and ISO 14001 approach and examine the applicability of the initial proposed conceptual framework in the meat industry. The findings from the interviews are used to verify and build upon the initial proposed framework of lean and ISO 14001. This framework is proposed for policy deployment and implementation by industry practitioners as well as use by academia for future studies. Assessing the applicability of the proposed conceptual framework for implementation in industry and future studies based on the insights captured from lean and ISO 14001 consultants, who are the most knowledgeable on these strategies, is the main contribution of this paper. This study is limited to lean and ISO 14001 consultants since they 
are the experts in this field and have vast experience in implementation of these strategies in multiple organizations, therefore their insights are valuable and would be importance to practitioners in industry. A drawback of this approach is that experiences from practitioners who have implemented these strategies in specific contexts of process improvement in the meat industry have not been captured and the personal agendas of the consultants could bias the results. However, the interview process ensured that such biases would be minimal (e.g., the consultants were asked to give examples of successful and unsuccessful implementations). Therefore, the in-depth information from well-informed consultants who are the most knowledgeable in this field is appropriate for the study results.

The remaining sections of this paper address the following. Section 2 covers the literature on lean and related environmental performance. Section 3 reviews ISO 14001 and its relationship with environmental performance. Section 4 discusses the integration of both lean and ISO 14001 strategies. Section 5 explains the research methodology used for this study. Section 6 presents the interview findings. Section 7 discusses the findings with the development of a revised framework and section 8 presents the conclusions.

\section{Lean and environmental performance}

Toyota company laid the foundation of Toyota production systems (TPS) when they started car manufacturing after the second world war by introducing flexible production systems (Droste, 2007). Lean is a continual improvement strategy based on the TPS philosophy for cost and waste reduction through quality control, measurement and improvement. As a management philosophy, lean was first introduced through the book "The Machine That Changed the World" by Womack et al. (2007). Lean paradigm is a combination of different management improvement initiatives which can be applied in a well-organized sequence to enhance productivity and cost-effective operations for increasing customer satisfaction in both manufacturing and service industry (Duarte and Cruz, 2017). Six sigma is another effective methodology for reducing variation and process defects in operations (Ali et al., 2020). LSS as a combined process improvement approach has been employed for over the last three decades for improving operational efficiencies and reducing causes of defects in business processes (Antony et al., 2019). With the focus of lean on waste elimination and improving operational efficiencies and the emphasis of six sigma on controlling process variation and reducing defects, lean has been more commonly adopted as an operational improvement strategy in industry that can have a significant impact on environmental performance (Antony et al., 2019).

Lean tools and practices are largely utilized in the food processing sector (Costa et al., 2018; Dora et al., 2016) especially in the meat processing facilities (Cox and Chicksand 2005; Zokaei and Simon, 2006) for improving production efficiency and product quality. Further, based on an empirical study investigating the impact of lean tools (value stream mapping (VSM), root cause analysis and standardized work) on environmental sustainability in the food sector (Powell et al., 2017), VSM and root-cause analysis helped in identifying operational waste while standardized work reduced operational losses leading to an improved environmental performance. Similarly, Simon and Zokaei (2005) conducted a multiple case study to determine the impacts of lean practices in the "meat cutting room". Findings of this study pointed out a $25 \%$ productivity gap between lean (non-adopting and adopting) meat facilities. Later, Zokaei and Simon (2006) conducted another case study in nine red meat facilities by exploring the impact of lean concepts (takt-time and standard operations) for identification of waste minimization. Implementation of lean techniques and practices improved the meat value chain and proposed a potential cost saving (2-3\%) in the meat processing facilities. In another study, Pampanelli et al., (2014) projected the potential application of their proposed framework for implementing lean and environmental improvement initiatives to reduce the consumption of 
resources by $30-50 \%$ and attain cost reduction of approximately $5-10 \%$. In yet another empirical study by Bai et al., (2018), the researchers identified the impact of lean practices on environmental and operational performance in six manufacturing facilities. In these studies, lean practices such as root case analysis, continuous improvement, customer and supplier involvement, concurrent engineering and design clearly showed a positive link with environmental performance. The three main pillars of lean (just in time (JIT), Jidoka and respect of people) were examined by Sartal et al., (2018) to determine their impact on environmental performance through a longitudinal case study. The findings of their study indicated a strong relationship between lean practices and environmental performance.

Several researchers (e.g., Belekoukias et al., 2014; Chiarini, 2014; Dieste et al., 2020; Garza-Reyes et al., 2018) have concluded that lean tools such as JIT, Kaizen, VSM, total productive maintenance (TPM), visual management, single minute exchange of die (SMED), 5S (seiri, seiton, seiso, seiketsu, shitsuke), work standardization and cellular manufacturing show a positive impact on sustaining environmental performance.

\section{ISO 14001 and environmental performance}

Since the official launch of ISO 14001 in 1996, 312,580 manufacturing and service facilities have certified their environmental management system to this international standard (ISO, 2019). The implementation of ISO 14001 is a structural strategy focused on reducing environmental impacts by introducing improvements in operational systems (Foster, 2010). ISO 14001 provides guidelines for developing an EMS, conducting environmental audits and obtaining ISO certification (Fortuński, 2008). The improvement in internal processes by reducing environmental aspects (air emissions and waste generation) and an increase in production efficiency are the main benefits of an effective ISO 14001 implementation. An EMS facilitates in (1) preventing waste generation (air emissions and solid waste), (2) fulfilling the legal and operational compliance requirements and (3) achieving operational and environmental benefits (Djekic et al., 2014; Massoud et al., 2010). Djekic (2015) identified the reasons for implementing ISO 14001 based EMS in the meat industry. Findings of this research suggested that ISO 14001 implementation in the meat processing facilities brings improvement in environmental performance, market competitiveness and increase in sales volumes.

Manufacturing industry adopts EMS to receive substantive environmental benefits and performance by legitimizing their environmental initiatives (Boiral and Henri, 2012). Wong et al., (2017) analyzed the impact of EMS implementation on environmental performance parameters (total suspended particulates and sulfur dioxide) in an ISO 14001 certified power plant. The study outcomes suggested that the certified power plant achieved better environmental performance than operational performance due to the effective environmental management compliance system of EMS. The main reasons for implementing ISO 14001 are identified by Sorooshian and Ting (2018) through a comprehensive analysis of interview data collected from 31 consultants of EMS. The findings of this study suggested that reduction of pollution, awareness of environmental issues as well as compliance with regulatory and laws requirements could be enhanced by implementing EMS in Malaysian manufacturing industry. Further, the majority of scholarly literature suggests that ISO 14001 as a management system is utilized for sustaining environmental performance in the manufacturing industry (Arimura et al., 2016; Campos et al., 2015; Nguyen and Hens, 2015; Testa et al., 2014).

A deeper integration of different management systems can be achieved by focusing on the PDCA cycle for continual improvement (Kurdve et al., 2014). By implementing different strategies as a combined approach, the duplication of similar management activities (e.g., auditing) can be avoided. An integrated management system is a set of processes that allows an organization to develop an integrated design for executing different management initiatives and evaluating the outcomes of these initiatives continually (Kruse et al., 2019). 


\section{A framework for integration of lean and ISO 14001}

An integrated conceptual framework of lean and ISO 14001 implementation has been proposed (Figure 1) for sustaining environmental performance by Ahmed and Mathrani (2019). The main strength of this conceptual framework is in its integrated policies and procedures of ISO 14001 and lean tools and techniques for sustaining environmental performance on an on-going basis. The proposed lean and ISO 14001 framework is built upon a continual improvement process through the PDCA cycle.

\section{***Insert Figure 1 about here ${ }^{* * *}$}

The framework illustrates that the environmental and waste reduction policies of ISO 14001 and lean implementation are developed, documented and communicated to all relevant stakeholders in the "plan" phase of PDCA. These policies link with the integrated environmental waste management plan (IEWMP) in the framework through a bold arrow which represents the integration relationship (e.g., waste elimination policies of both) and dotted arrow which depicts non-combined impacts of both policies (e.g., legal implications from ISO and operational benefits of lean). Once the policies for lean and ISO 14001 are documented, it becomes possible to create a clear plan for IEWMP. The "do" phase of PDCA's cycle starts from IEWMP until the implementation stage in this conceptual framework. The communication, environmental process improvement projects (EPIP) and operational procedures of both strategies start simultaneously indicated through bold arrows. The inbetween dotted lines depict their interrelationships. The operational procedures are divided into lean tools and techniques as well as process control initiatives (operational control, documentation control, and roles and responsibilities). The implementation stage starts on the basis of the outputs from the above three processes. The "control" is the next phase of PDCA which is demonstrated by a bold arrow depicting a link between implementation and controlling stage in the framework. The controlling stage comprises of monitoring and reporting on the implemented operational procedures as well as their review and audit. The improvements are based on the outcomes of the "act" phase. The continual improvement in this integrated lean and ISO 14001 framework is achieved by the PDCA cycle through effective management of environmental audits, monitoring and measurement of environmental management by proposing improvement (proactive, preventive and corrective) actions. 
This framework guides the conduct of this study in collecting empirical evidence from the NZ based meat industry and validating the application of lean and ISO 14001 implementation as a combined approach for environmental performance. The interview findings from this study are used to further build upon this framework for use by academia in future studies and practitioners in future implementations industry.

\section{Research methodology}

A case study methodology has been adopted to collect information on the implementation of an integrated lean and ISO 14001 approach in the NZ based meat industry for environmental performance and to add richness to the conceptual framework (Figure 1). The findings elaborate how lean and ISO 14001 can be unified within the PDCA cycle. A case study approach provides the flexibility and simplicity in explaining the critical and complex functions of lean practices and ISO 14001 as an integrated strategy to achieve the objectives of this study (Persis et al., 2020). Further, this methodology helps to create an understanding in the adoption of philosophies and developing new theories such as in this case adoption of lean and ISO 14001 as a joint strategy for sustaining environmental performance, that can set the foundation for future validation of implementation outcomes.

For collecting data, initial contact was made with the lean and ISO 14001 consultants through an email request providing relevant information for participation. Six interviews were conducted with the consultants (one with each consultant) that lasted between 45 to 90 minutes. The interviews were held between March and July 2020 via Zoom ${ }^{\circledR}$ and were based on predecided questions. According to Morse (1994) and Dorwiken (2012), a minimum of five to six interviews are considered adequate for theoretical saturation in qualitative research. Additionally, Eisenhardt (1989) has suggested that the ideal number of cases ranges between 4 and 10, depending on the breadth and depth of cases. In this study, six in-depth case interviews with the well-informed lean and ISO 14001 consultants were adequate for achieving theoretical saturation as incremental learning was found minimal close to the final interviews (Eisenhardt, 1989; Zsidisin et al., 2005). The interviews were semi-structured that allowed the use of some unstructured formats with an approach to extract optimal information from the informants (Dikko, 2016). Other data collection methods such as organizational documents, informant observation and archival records were also used (Yin, 2014).

The consultant participants were managing directors, managers, and senior consultants in their respective companies who were experts in lean and/or ISO 14001 implementation in the meat industry. These participants have been involved in many implementations of these programs in multiple meat processing facilities in NZ. Table 1 depicts the respondents' background. Questions were asked about the applicability and suitability of implementing lean and ISO 14001 as an integrated strategy in the meat industry based on the framework constructs (Figure 1) that guided the interview process.

\section{***Insert Table 1 about here***}

The interviews were digitally recorded with the informant's permission and subsequently transcribed by using the match transcription technique. NVivo 11 Starter for Windows was utilized for data analysis in developing codes, trends and themes based on the interview findings of this study.

\section{Interview findings}

The findings highlighted nine themes that emerged through the coding of interview transcripts revealing a strong relationship between lean and ISO 14001 as an integrated approach for sustaining environmental performance in the meat industry. 


\subsection{Integrated lean and ISO 14001 policy}

Lean-ISO1 explained that the lean and ISO 14001 policies are like foundational bricks for building a house. If the brick is put in the wrong place or it slightly deviates from where it should be, the entire house could later have quality issues. Therefore, lean and ISO 14001 policies are highlighted as foundational documents for establishing the plans, objectives and targets for achieving the environmental performance. Lean-ISO1 further elaborated that an integrated lean and ISO 14001 policy is included as a part of the organizational commitment and intention in defining and implementing the environmental waste reduction objectives and targets. Further, Lean-ISO2 emphasized that an integrated lean and ISO 14001 policy based on SMART (specific, measurable, assignable, realistic and time-related) environmental goals and objectives can be utilized in developing a culture for environmental sustainability. At the operational level in the meat industry, a management system is established by placing the processes and procedures for meat manufacture to achieve the environmental objectives and targets. ISO-1 defined the environmental and waste minimization policy as follows:

High-level document that guides the effectiveness of that system is the policy. A policy illustrates top management's commitment and their intent: what do they want to achieve in the next twelve months? And this is all very nicely ring-fenced in this environmental and waste reduction policy.

Lean-ISO1, lean-1 and ISO-1 suggested that the meat industry must have an integrated policy instead of separate lean and ISO 14001 policies for environmental and waste minimization. Lean-ISO1 explained that operational productivity and environmental performance can be enhanced in the meat facilities by setting coherent environmental and waste minimization objectives and goals for implementing lean and ISO 14001 as a combined approach. Further, ISO-1 elaborated that an integrated policy can include waste minimization, emission reduction, water quality and environmental policies in one overarching policy document for achieving sustainable environmental performance. Lean-1 and Lean-2 have further suggested that the vision and mission of an organization for environmental waste minimization must be included for achieving more clarity in articulating an integrated policy of lean and ISO 14001. Lean-1 emphasized that a policy for environmental and waste minimization must be stemmed out from the values (small virtues), and the mission and vision of an organization, in order to provide the underpinning support.

The informants explained that the objectives and targets need to be SMART for executing lean and ISO 14001 as an integrated approach. Further, aligning the SMART objectives with organizational values, vision and mission is instrumental in achieving better operational excellence and environmental performance during the different stages of an improvement program.

\subsection{Communication and information sharing}

Communication is an important aspect for implementing an integrated lean and ISO 14001 transformation program. A comprehensive communication management helps an organization in maintaining information flow and improving industrial competitiveness. Lean-1 noted that frustration and confusion among the workforce in implementing a combined lean and ISO 14001 approach can be minimized by managing an effective communication system. The top management is responsible for communicating strategic objectives and goals with all stakeholders for transforming lean and ISO 14001 program. Lean-2 pointed out that the quality and environmental issues are communicated with internal and external stakeholders by displaying them in visual indicators in the meat industry. Visual management is used as a communication tool for clarifying the goals and targets to achieve environmental sustainability. Lean-ISO1 and Lean-ISO2 suggested that visual management (e.g., team/white board, or QCD (quality, cost and delivery) board, or SQCDP (safety, quality, cost, delivery and people) board) 
must be included for communication to improve the information sharing channels in implementation of lean and ISO 14001 as an integrated strategy.

\subsection{Integrated environmental and waste minimization plan and projects}

Findings of this study reveal that an environmental waste management plan has a strategical importance in implementing lean and ISO 14001 approaches as environmental process improvement projects in the meat industry. Lean-2 elucidated that an environmental waste management plan is used for identifying the key performance indicators and setting up an action plan to execute environmental process improvement projects. ISO-1 described environmental waste plan as a strategic initiative:

An environmental plan is a list of the environmental waste actions, which should be performed, or what are we going to do? That is our strategic plan and is normally for the next year or two, or if it is long-term, it is for the next three to five years.

Environmental improvement projects can be pursued by executing a waste reduction action plan through implementation of lean and ISO 14001. ISO-1 further explained that environmental improvement projects help in achieving strategic milestones of an organization and these projects produce positive outcomes:

A project includes the actual environmental improvement process for execution of these actions, these little milestones for achieving that plan overall. And yes, I definitely believe in having an integration of ISO 14001 and lean, that if you have an integrated plan and an integrated project, which is effectively implemented, you will have effective results.

Moreover, ISO-1 explained that the top managements propose many environmental waste management plans and projects for achieving the desired environmental objectives and targets. During execution of these environmental process improvement projects, internal audits and performance review meetings are carried out to measure the effectiveness of management initiatives and identify the performance gaps. These performance gaps can be minimized by incorporating appropriate changes in the planning and execution phases of environmental process improvement projects. An integrated environmental waste management plan and environmental process improvement projects can be executed by implementing operational procedures of ISO 14001 and leans tools according to the initial framework of this study. However, ISO-2 suggested that a new dimension "problem/non-conformance management" can be included for rectifying the potential occurrence of non-conformity or problem in implementing environmental process improvement plans and projects.

\subsection{ISO 14001 procedures}

Lean-ISO1 suggested that environmental policy is the most important procedure in identifying risks as well as opportunities and proposing an action plan to achieve environmental goals and objectives. Lean-ISO2 explained that the operational controls of ISO 14001, emergency preparedness plan, documentation, communication, roles and responsibilities, nonconformance and corrective actions are considered as the other critical procedures to implement EMS. ISO-2 explained that the operational planning and control is also a critical aspect in ISO 14001 to maintain an effective meat processing process (from meat carcass till the packaging of the meat-products). Further, the other most important ISO 14001 procedures are assigning the responsibilities, identifying non-conformance and educating the workforce to improve environmental performance.

\subsection{Lean tools}

Lean-1 explained that Hoshin Kanri (a lean tool) can be used as a foundation block in establishing the strategic direction for improving environmental performance: 
There are tools like you know, do your strategic planning. We call it Hoshin Kanri in Japanese. So, you need to apply Hoshin Kanri, cascading your policies and your strategy down to the coalface so that everybody is on the same page.

The successful implementation of another important lean tool, 5S, is also sometimes considered as the first step in implementing the lean strategy. 5S consists of a set of selfdiscipline activities for sustaining workplace cleanliness and improving environmental performance continually in the meat industry. Lean-1 narrated about their meeting with founder of Kaizen institute, Mr. Masaaki Imai, to explain the importance of 5S implementation:

$5 S$ is a very important tool. Our founder, Masaaki Imai, says that if you can't do $5 S$, you can't do lean, you can't do Kaizen. You must be able to commit to the smaller things like cleaning every single day. If you can't do that, I tell you, you haven't got the discipline to make the bigger improvements in your organization. It all starts with small, little self-discipline activities in an organization, that will lead to excellence and will lead to environmental improvements as well.

Lean-ISO1, Lean-1 and Lean-2 have strongly suggested that 5-whys, fishbone diagram and A3 thinking can be used to determine main root-cause of the environmental problems, suggest and implement corrective/preventive measures for resolving problems continually in the meat industry. Lean-ISO2 explained that JIT and kanban are utilized to fulfil the desired quantity of an order by a customer. Once a customer places an order, the concept of JIT is used to estimate the livestock required and the kanban ticketing system assists in producing meat-products based on the demand. Calculating the required number of livestock and executing the ticketing system means less generation of operational waste and air pollutants into the environment. Further, a machine operator is guided through a step-by-step approach or written guidelines or flow diagrams to produce meat-products smoothly and improve sustainability in the meat processing.

Lean-ISO1 further explained the importance of JIT application to maintain an appropriate level of stock for meeting the required demand of meat and thus avoiding the maintenance cost to handle excessive meat carcass. One day worth of meat stock can be placed as a buffer to avoid the impact of stock being late or handling excessive meat carcass in the meat industry. Furthermore, total preventative maintenance (TPM) is used as a tool for avoiding breakdowns and accidents by monitoring and maintaining the equipment and machinery. Lean- 2 noted that heavy machinery such as blister wrapping, and meat slicer machines are maintained by avoiding the occurrence of processing abnormalities in meat facilities by autonomation. Higher level of lean tools such as rapid changeovers (SMED) and autonomation are effectively implemented by competent workforce in meat processing.

\subsection{Lean tools and ISO procedures as a combined approach for environmental performance} Lean-ISO2 highlighted a comprehensive relationship between lean tools and ISO 14001 procedures as a combined approach. According to lean-ISO2, 5-whys and fishbone diagram are basic and well-established lean tools for identifying the root cause of problems which can assist in setting environmental objectives, compliance and continuous improvement processes based on the requirements of ISO 14001. The safety, quality, cost, delivery and performance (SQCDP) board as a visual indicator (visual management) is used to compliment communication as part of lean, which is also a key requirement for ISO 14001. This includes a visual representation of environmental targets highlighted on a single board for better communication and execution. Further, lean tools and ISO 14001 procedures have synergies of combining audit programs by applying 5S audits as well as internal audits based on the EMS protocol. Procedures for monitoring and evaluation of the environmental performance are combined with SQCDP board (visual management) and value stream mapping processes. 
Moreover, documentation of lean and ISO 14001 is maintained and displayed into a visual management flow that would be accessible and understandable to all stakeholders.

\subsection{Competency level assessment and skill development programs for sustaining environmental performance}

This study has revealed that competence, awareness and training of the workforce plays a pivotal role in implementing an integrated lean and ISO 14001. Competency (knowledge, skill and behavior) of the workforce and awareness programs are fundamental in understanding the strategic values, objectives and targets for reducing environmental impacts. In the absence of experienced workforce in these strategies, a training program is initiated to improve competency levels for raising operational productivity and environmental performance. The presence of a competent workforce means that the employees have sufficient knowledge and professional skills to escalate and attain higher performance levels:

Training and awareness are not as high in skills as competency. So, if you replace that with competency, you improve, you escalate the quality and the knowledge of your system one or two steps higher.

Training programs are planned and executed based on a training needs matrix. This matrix is a tool for organizing and displaying the status of strengths and weaknesses of an individual. ISO-1 explained that induction and subsequent detailed training are carried out to improve the knowledge and skill levels of the workforce for executing the lean and ISO 14001 approaches. Lean-1 suggested that an internal training program is the best method for a company management to educate their workforce otherwise they can start off with external professionals to get the ball rolling. External training programs must lead to achieving internal benefits by improving the skills and knowledge of the workforce in implementing lean and ISO 14001. ISO-2 stated that the internal training (e.g., induction) for newly hired employees and inexperienced workers and supervisors helps the workforce to perform the meat processing tasks effectively. Furthermore, the technical aspects of meat processing to maintain meat properties can also be taught through external courses and training programs.

\subsection{Environmental performance review}

Data from monitoring and reporting records are utilized for periodic evaluation of the environmental waste minimization objectives. The performance evaluation parameters and strategic directions of the meat industry for minimization of waste are communicated with all stakeholders at regular intervals. ISO-2 stated that performance evaluation is conducted by measuring, evaluating, and reporting on key parameters. Further, outcomes of the performance evaluation (conformance or non-conformance) and corrective actions are communicated to all stakeholders on a weekly, monthly and annual basis for improvement and controlling.

An effective audit program of lean and environmental management system is utilized in improving environmental performance continually. Regular audits are carried out to maintain the process checking, monitoring and reporting system in the meat industry. Lean-2 explained that any environmental program always starts by analyzing the currently reported data on environmental aspects such as the air emission status and waste generation through operational losses to understand the environmental impacts. Lean-ISO2 additionally stated that a continual environmental performance evaluation includes internal auditing to identify non-conformances and corrective actions through on-going checking and reporting, for achieving the waste reduction targets. Records of environmental, safety and operational incidents are effectively maintained during the checking and reporting phases of performance review. An effective implementation of 5S audits and internal audits of ISO 14001 enables companies to identify the nonconformities in the meat processing industry. However, the frequency of an internal audit is the most important factor to provide performance data for analysis on a regular basis, 
generated during lean and ISO 14001 implementation. ISO-1 suggested that an internal audit must occur frequently (if possible on a weekly basis) for helping an organization in producing statistical trends to evaluate the performance of their meat facilities. Lean-ISO1 recommended that effectiveness of an integrated lean and ISO 14001 audit can be enhanced by incorporating corrective actions, suggestions and learning initiatives in this holistic evaluation program.

\subsection{Environmental management review}

Management reviews are structural meetings for analyzing the current performance as well as recommending new initiatives and corrective actions to improve the existing procedures and processes in an organization. ISO-1 stated that the management and improvement reviews help the meat firms in creating an organizational culture to manufacture environmentally friendly meat-products. These reviews also assist in identifying the role of the top management to establish a sense of accountability in the workforce for achieving environmental performance: We've got a saying: 'garbage in, garbage out'. The example that management is setting becomes the culture. Management review is a very important word for the entire organization. So, by management, doing management reviews and improvement reviews, they are setting an example and a culture that we care about and it's not about just business and bottom-line profit.

Management reviews are used to measure the effective implementation of objectives and targets, identify the potential reasons for failures and propose improvement initiatives/ corrective actions in the manufacturing environment. Lean-2 explained that a management review based on monthly reports can dig out the issues in meat processing such as reasons for production delays. It enables the top management to remove the bottlenecks, keep tracking the improvement programs and hold the workforce to account for improving the organizational performance. Lean-ISO1 suggested that management reviews can effectively be carried out by evaluating the criteria of performance, and monitoring and measuring in the improvement evaluation phase.

Successful implementation of lean and ISO 14001 is effectively maintained by receiving continual feedback on the environmental improvement initiatives from the workforce, suppliers and customers. Lean-ISO2 noted that an analysis of the performance parameters such as environmental key performance indicators (e-KPIs) is carried out to identify the leading or lagging parameters for improvement. Corrective actions with revised performance goals can be proposed including use of latest technologies and state-of-art equipment to mitigate the nonconformities in meat processing. Lean-1 explained that more frequent management reviews based on constructive feedback timely provide the guidelines to the top management in improving areas required for environmental performance. Further, ISO-1 stated that the management reviews must be conducted quarterly or at least after every six months. However, once a year is just not adequate for continual improvement in the meat industry.

\section{Discussion}

This study has investigated the implementation of an integrated lean and ISO 14001 strategy in the meat industry for environmental performance. Interview findings suggest that an integrated lean and ISO 14001 implementation can raise operational productivity and enhance environmental performance based on the synergistic impact of the two strategies. An integrated policy based on the vision, mission and values of an organization helps in achieving SMART objectives, targets and business excellence. Policy, goals and objectives provide a strategic direction in implementing multiple manufacturing improvement initiatives for achieving business excellence (Johnson et al., 2007). Salleh et al., (2015) have emphasized that an organizational policy for environmental, quality and lean implementation provides a driving force to satisfy customers, comply regulatory and statutory requirements, and streamline lean 
value stream activities. A strategic direction of an organization for elimination of waste (operational or environmental) is set by considering the organizational values, vision and mission (Bellisario and Pavlov, 2018; Oliveira and Serra, 2008). Moreover, environmental objectives and targets are derived from the organizational strategic intent before implementing an integrated lean and ISO 14001 program. The SMART method is used in developing measurable goals and objectives for implementing and monitoring a management improvement program (Bjerke and Renger, 2017), that can help an organization in setting the strategic direction for implementing an ISO management system and lean as a combined approach (Salleh et al., 2015), which is consistent with the findings of this study.

This study emphasizes that an integrated policy of lean and ISO 14001 implementation must be cascaded down to all levels through an effective communication channel. An outline for internal and external communication between different organizational stakeholders for achieving policy, objectives and targets as an integrated management initiative must be developed (Kruse et al., 2019). Further, Souza and Alves (2018) have emphasized that the employees should be informed about the implementation of management initiatives and process improvement activities during the planning and improvement phase. A joint implementation plan would provide more clarity in aligning ISO 14001 operational procedures with lean tools and techniques for an enhanced environmental performance outcome. The tool provides clear guidelines, continual feedback and information to the teams on their current performance and future improvement initiatives (Eaidgah et al., 2016). Visual management (a lean tool) aligned with ISO 14001 communication procedure can share information more accurately and transparently with relevant stakeholders in an integrated communication program. Visual management as a lean tool is used for reducing waste (solid, air emissions and hazardous material), and improving resource utilization (energy, material and water) in the manufacturing facilities (Dieste et al., 2020), which aligns with this study's findings.

Stakeholders are considered as an influential group of people for successful implementation of a management improvement initiative to achieve operational excellence (Elias, 2016). Elias (2019) has explained that media, Government, customers/taxpayers, special interest groups, private sector, supplier and internal stakeholders are included in a stakeholder map for implementing improvement initiative projects. Further, stakeholder attributes such as top management approach and customer satisfaction can facilitate in implementing process improvement strategy, which supports the interview findings of this study. From a joint lean and ISO implementation perspective, the strategic policy deployment depicted separately for lean and ISO in Figure 1, which include the top and middle managements, customers, suppliers, and consultant groups as stakeholders are combined in Figure 2, to reflect a joint policy deployment of both strategies to create more value as regards environmental performance.

Lean tools and ISO 14001 procedures together can holistically assist in implementing, monitoring and evaluating environmental plans and projects initiatives. This study has validated the applicability of essential lean tools (e-VSM, JIT, TPM, kaizen, standardized work, 5S, SMED, kanban and autonomation) for improving environmental and operational performance, which aligns with literature (e.g., Belekoukias et al., 2014; Dieste et al., 2020; Garza-Reyes et al., 2018). 5S as a lean tool helps the manufacturing and service departments in maintaining workplace organization, improving product quality, and reducing waste (operational and environmental) (Durakovic et al., 2018). Further, 5S is considered as a basic lean tool in making an organization neat and standardized for implementing the lean philosophy (Gupta and Jain, 2013). The kanban system enables maintaining the required material movement between the different workstations in a single production line for achieving better product flow (Gupta and Jain, 2013) which validates the findings. Standardized work enables a processing facility to achieve the same results all the time by providing the best measurable operational practices for continual improvement (Oliveira et al., 2017). 
Further, the informants of this study added a few extra lean tools such as Hoshin Kanri, root cause analysis (5-whys and fishbone diagram), A3 thinking, KPI's and visual management for achieving better operational and environmental performance in the meat industry. Hoshin Kanri as a foundational lean tool that sets up the strategic direction for enhancing and sustaining environmental performance continually (Tortorella et al., 2019). Additionally, root cause analysis is a structural problem-solving tool for improving product quality and customer satisfaction by reducing waste problems and scrap losses (Gangidi, 2019; Murugaiah et.al, 2010) and fishbone diagram by considering the 4M's, i.e., man, machine, material and measurement (Ashok et al., 2013; Gangidi, 2019). 5-whys, fishbone diagram and A3 thinking are basic tools in determining the reasons for environmental problems through the brainstorming method and proposing preventative actions (Ashok et al., 2013; Gangidi, 2019; Tortorella et al., 2019). Further, the A3 thinking is a powerful lean tool for achieving a consensus in solving complex problems and promoting continual improvement. These additional lean tools are recommended to be incorporated in the initial conceptual model to achieve better environmental performance based on an integrated lean and ISO 14001 implementation strategy as depicted in Figure 2. The interview findings suggested that aspects of an integrated process (environmental policy, identification of process non-conformities and environmental improvement program, communication, documentation process, audit, monitoring and performance evaluation) can be maintained by combining lean tools and ISO 14001 procedures together for environmental sustainability. A summary of the lean and ISO 14001 procedures employed as a combined approach for environment initiatives are presented in Table II.

$$
\begin{aligned}
& * * * \text { Insert Figure } 2 \text { about here } * * * \\
& * * * \text { Insert Table II about here } \\
& * * *
\end{aligned}
$$

Findings confirm that training and awareness programs are necessary in creating the skills and competencies of the workforce for enhancing operational efficiencies and environmental performance in the meat industry, therefore this aspect is included in Figure 2 in the implementation phase. The lack of knowledge in installation of new technologies, lean tools and management practices can be improved through employee training programs (Alefari et al., 2017). Different responsibilities are assigned to the senior, middle and lower-level workforce based on their skills and experience with sufficient financial and technical resources for further improving skills through training and development programs (Muralikrishna and Manickam, 2017). This study has indicated the potential occurrences of problems/nonconformances while executing IEWMP and EPIP through implementation of lean tools and ISO 14001 operational procedures. These occurrences can be rectified by a problem/nonconformance management initiative for sustaining environmental performance. Problem/nonconformance management is part of the "controlling" activity through corrective actions in the "check" phase of PDCA. For effective execution of lean and ISO 14001, an integrated performance evaluation can be used to confirm conformance or non-conformance and suggest corrective and preventive actions. Corrective actions and suggestions on the basis of audit program are also proposed for improving product quality, lowering operational expenses and increasing customer satisfaction (Lenning and Gremyr, 2017). Further, implementation of a successful integrated audit program needs a competent audit team for reviewing documents, identifying non-conformities and proposing corrective/preventive actions. Management reviews are conducted to evaluate current performance of the meat facilities and recommend future process improvements for producing environmentally friendly meat-products. The integrated improvement program can be strengthened by including criteria parameters and procedures for monitoring and measuring through process evaluation in the "act" phase of 
PDCA. A revised conceptual framework for an integrated lean and ISO 14001 implementation is shown in Figure 2.

\section{Conclusions}

This article provides empirical support for implementing lean and ISO 14001 as an integrated strategy for sustaining environmental performance in the meat industry. The results of this study have indicated that an integrated policy for lean and ISO 14001 implementation provides a clear vision for achieving SMART objectives and goals as well as business excellence. An integrated communication program is required to maintain an efficient information flow by sharing environmental and waste minimization objectives and targets with relevant stakeholders in achieving environmental sustainability. Execution of integrated plans and projects by implementing lean tools and ISO 14001 procedures together can help in effective utilization of resources and minimization of waste in the meat industry. Training and awareness programs can assist meat processing facilities in enhancing the competencies of the workforce for achieving operational productivity and environmental performance.

An integrated performance and management review can monitor and audit the existing status of the meat processing facilities and propose future improvement initiatives in enhancing sustainability. These study outcomes clearly highlight the importance of a joint lean and ISO 14001 for a synergistic positive impact in sustaining environmental performance. The revised conceptual framework (Figure 2) provides a clear roadmap for an implementation programme which can assist academia and practitioners for conducting future studies in lean and ISO 14001 implementation as an integrated approach. Practitioners can implement lean and ISO 14001 as a combined approach for achieving operational and environmental performance benefits.

The main limitation of this paper is that only six semi-structured interviews were conducted with lean and ISO 14001 consultants, however the in-depth nature of information from wellinformed consultants who are the most knowledgeable in this field is appropriate for the study results. Future research can extend this study to practitioners who have deployed these strategies in meat manufacturing facilities to capture their implementation experiences. Future research can also be conducted in other industrial facilities or service (healthcare, education and banks) sectors to investigate the adaptability of lean and ISO 14001 mechanism as an integrated strategy. The revised framework in this study can be used for an integrated lean and ISO 14001 implementation that would help researchers and policymakers in conducting future evaluation for streamlining the operational processes to increase profitability, improve competitive advantage and achieve sustained environmental performance. Furthermore, this research study was done within the NZ context; similar studies in meat industry or different manufacturing sectors could be conducted in other advanced economies such as the UK, Australia and USA to reconfirm the findings of this research.

\section{References}

Abdullah, R., Ismail, Z. \& Smith, M. (2018), "Audit committees' involvement and the effects of quality in the internal audit function on corporate governance", International Journal of Auditing, Vol. 22 No. 2, pp. 385-403.

Aguado, S., Alvarez, R. \& Domingo, R. (2013), "Model of efficient and sustainable improvements in a lean production system through processes of environmental innovation", Journal of Cleaner Production, Vol. 47, pp. 141-148.

Ahmed, A. \& Mathrani, S. (2019), "A conceptual model of ISO 14001 and lean integration for evaluation and improvement of environmental performance in manufacturing industry", Proccedings of the $50^{\text {th }}$ Decision Sciences Institute conference, New Orleans, USA, pp. 26382649. 
Ahmed, A., Mathrani, S., \& Jayamaha, N. (2020), "Barriers for an Integrated Lean and ISO 14001 Implementation for Sustaining Environmental Performance in the Manufacturing Industry”, 2020 IEEE Asia-Pacific Conference on Computer Science and Data Engineering (CSDE), pp. 1-5.

Alefari, M., Salonitis, K. \& Xu, Y. (2017), "The Role of Leadership in Implementing Lean Manufacturing", Proceedings of the 50 ${ }^{\text {th }}$ CIRP conference on Manufacturing Systems, Cranfield University, UK, pp. 756-761.

Ali, Y., Younus, A., Khan, A. U., \& Pervez, H. (2020), "Impact of Lean, Six Sigma and environmental sustainability on the performance of SMEs", International Journal of Productivity and Performance Management, Vol. ahead-of-print No. ahead-of-print.

Antony, J., Sony, M., Dempsey, M., Brennan, A., Farrington, T., \& Cudney, E. A. (2019), "An evaluation into the limitations and emerging trends of Six Sigma: an empirical study", The TQM Journal, Vol. 31 No. 2, pp. 205-221.

Arimura, Darnall, N., Ganguli, R. \& Katayama, H. (2016), "The effect of ISO 14001 on environmental performance: Resolving equivocal findings", Journal of Environmental Management, Vol. 166, pp. 556-66.

Ashok Sarkar, S., Ranjan Mukhopadhyay, A. \& Ghosh, S. K. (2013), "Root cause analysis, Lean Six Sigma and test of hypothesis", The TQM Journal, Vol. 25 No. 2, pp. 170-185.

Bai, C., Satir, A., \& Sarkis, J. (2018), "Investing in lean manufacturing practices: an environmental and operational perspective”, International Journal of Production Research, Vol. 57 No. 4, pp. 115.

Bateman, N., Philp, L. \& Warrender, H. (2016), "Visual management and shop floor teams development, implementation and use", International Journal of Production Research, Vol. 54 No. 24, pp. 7345-7358.

Belekoukias, I., Garza-Reyes, J. A. \& Kumar, V. (2014), "The impact of lean methods and tools on the operational performance of manufacturing organisations", International Journal of Production Research, Vol. 52 No. 8, pp. 5346-5366.

Bellisario, A. \& Pavlov, A. (2018), "Performance management practices in lean manufacturing organizations: a systematic review of research evidence", Production Planning \& Control, Vol. 29 No. 5, pp. 367-385.

Bjerke, M. B. \& Renger, R. (2017), "Being smart about writing SMART objectives", Evaluation and Program Planning, Vol. 61, pp. 125-127.

Borial, O., \& Henri, J. (2012), "Modelling the impact of ISO 14001 on environmental performance: A comparative approach", Journal of Environmental Management, Vol. 99, pp. 84-97.

Campos, L. M. S., de Melo Heizen, D. A., Verdinelli, M. A. \& Cauchick Miguel, P. A. (2015), "Environmental performance indicators: a study on ISO 14001 certified companies", Journal of Cleaner Production, Vol. 99, pp. 286-296.

Carson, J. K. \& East, A. R. (2018), "The cold chain in New Zealand - A review". International Journal of Refrigeration, Vol. 87 No. 1, pp. 185-192.

Chen, P.-K., Lujan-Blanco, I., Fortuny-Santos, J. \& Ruiz-de-Arbulo-López, P. (2020), "Lean Manufacturing and Environmental Sustainability: The Effects of Employee Involvement, Stakeholder Pressure and ISO 14001", Sustainability, Vol. 12 No. 18, pp. 1-19.

Chiarini, A. (2014), "Sustainable manufacturing-greening processes using specific Lean Production tools: an empirical observation from European motorcycle component manufacturers", Journal of Cleaner Production, Vol. 85, pp. 226-233.

Costa, L. B. M., Godinho Filho, M., Fredendall, L. D. \& Gómez Paredes, F. J. (2018), "Lean, six sigma and lean six sigma in the food industry: A systematic literature review", Trends in Food Science and Technology, Vol. 82, pp. 122-133.

Cox, A. \& Chicksand, D. (2005), “The Limits of Lean Management Thinking”, European Management Journal, Vol. 23 No. 6, pp. 648-662.

Dieste, M., Panizzolo, R. \& Garza-Reyes, J. A. (2020), "Evaluating the impact of lean practices on environmental performance: evidences from five manufacturing companies", Production Planning \& Control, Vol. 31 No. 9, pp. 739-756.

Dikko, M. (2016), "Establishing construct validity and reliability: Pilot testing of a qualitative interview for research in takaful (Islamic insurance)", Vol. 21 No. 3, pp. 521-528. 
Djekic, I. (2015), "Environmental Impact of Meat Industry - Current Status and Future Perspectives", Proceedings of $58^{\text {th }}$ International Meat Industry Conference on Meat Safety and Quality: where it goes", Belgrade, Serbia, pp. 61-64.

Djekic, I., Blagojevic, B., Antic, D., Cegar, S., Tomasevic, I. \& Smigic, N. (2016), "Assessment of environmental practices in Serbian meat companies", Journal of Cleaner Production, Vol. 112 No. 4, pp. 2495-2504.

Djekic, I., Rajkovic, A., Tomic, N., Smigic, N. \& Radovanovic, R. (2014), "Environmental management effects in certified Serbian food companies", Journal of Cleaner Production, Vol. 76, pp. 196-199.

Dora, M., Kumar, M. \& Gellynck, X. (2016), "Determinants and barriers to lean implementation in food-processing SMEs - a multiple case analysis", Production Planning \& Control, Vol. 27 No. 1, pp. 1-23.

Droste, A. (2007), "Lean thinking, banish waste and create wealth in your corporation", Action Learning: Research and Practice, Vol. 4 No. 1, pp. 105-106.

Duarte, S. \& Cruz Machado, V. (2017) "Green and lean implementation: an assessment in the automotive industry", International Journal of Lean Six Sigma, Vol.8 No. 1, pp. 65-88.

Durakovic, B., Demir, R., Abat, K. \& Emek, C. (2018), "Lean Manufacturing: Trends and Implementation Issues", Periodicals of Engineering and Natural Sciences (PEN), Vol. 6 No. 1, pp. 130-143.

Dworkin, S. L. (2012), "Sample Size Policy for Qualitative Studies Using In-Depth Interviews", Archives of Sexual Behavior, Vol. 41 No. 6, pp.1319-1320.

Eaidgah, Y., Maki Alireza, A., Kurczewski, K. \& Abdekhodaee, A. (2016), "Visual management, performance management and continuous improvement: A lean manufacturing approach", International Journal of Lean Six Sigma, Vol. 7 No. 2, pp. 187-210.

Eisenhardt, K. M. (1989), "Building Theories from Case Study Research. Academy of Management Review", Vol.14 No. 4, pp. 532-550.

Elias, A. A. (2016), "Stakeholder analysis for Lean Six Sigma project management", International Journal of Lean Six Sigma, Vol. 7 No. 4, pp. 394-405.

Elias, A. A. (2019), "Strategy Development Through Stakeholder Involvement: A New Zealand Study", Global Journal of Flexible Systems Management, Vol. 20 No. 4, pp. 313-322.

Farrukh, A., Mathrani, S. \& Taskin, N. (2020), "Investigating the Theoretical Constructs of a Green Lean Six Sigma Approach towards Environmental Sustainability: A Systematic Literature Review and Future Directions", Sustainability, Vol. 12 No. 19, pp. 1-29.

Fortuński, B. (2008), Environmental Assessment and Management in the Food Industry "Does the environmental management standard ISO 14001 stimulate sustainable development?: An example from the energy sector in Poland", Management of Environmental Quality: An International Journal, Vol. 19 No. 2, pp. 204-212.

Foster, C. (2010), "17 - Establishing an environmental management system in the food industry", in Sonesson, U., Berlin, J. \& Ziegler, F. (Ed.s), Environmental Assessment and Management in the Food Industry, Woodhead Publishing, United Kingdom, pp. 333-355.

Gangidi, P. (2019), "A systematic approach to root cause analysis using $3 \times 5$ why's technique" International Journal of Lean Six Sigma, Vol. 10 No. 1, pp. 295-310.

Garza-Reyes, J. A., Kumar, V., Chaikittisilp, S. \& Tan, K. H. (2018), "The effect of lean methods and tools on the environmental performance of manufacturing organisations", International Journal of Production Economics, Vol. 200, pp. 170-180.

Gupta, S. \& Jain, S. K. (2013), "A literature review of lean manufacturing. International Journal of Management Science and Engineering Management, Vol. 8 No. 4, pp. 241-249.

Gupta, S. \& Jain, S. K. (2015), "An application of 5S concept to organize the workplace at a scientific instruments manufacturing company", International Journal of Lean Six Sigma, Vol. 6 No. 1, pp. 73-88.

Habidin, N. F., Hibadullah, S. N., Mohd Fuzi, N., Salleh, M. I. \& Md Latip, N. A. (2018), "Lean manufacturing practices, ISO 14001, and environmental performance in Malaysian automotive suppliers", International Journal of Management Science and Engineering Management, Vol. 13 No. 1, pp. 45-53. 
ISixSigma (2021), "Low hanging fruit", available at: https://www.isixsigma.com/dictionary/lowhanginh-fruit/ (accessed 07 October 2021).

ISO (2019), "The ISO survey of management system standard certifications -2019 - explanatory note", available at: https:/isotc.iso.org/livelink/livelink/fetch/8853493/8853511/8853520/18808772/0. Explanatory note and overview on ISO Survey 2019 results.pdf?nodeid $=21413237 \&$ vernum $=-2$ (accessed 4 May 2021).

Johnson Dana, M., Sun, J. \& Johnson Mark, A. (2007), "Integrating multiple manufacturing initiatives: challenge for automotive suppliers", Measuring Business Excellence, Vol. 11 No. 3, pp. 41-56.

King, A. A., \& Lenox, M. J. (2001), "Lean and green? An empirical examination of the relationship between lean production and environmental performance", Production and Operations Management, Vol. 10 No. 3, pp. 244-256.

Kruse, T., Veltri, A. \& Branscum, A. (2019), "Integrating safety, health and environmental management systems: A conceptual framework for achieving lean enterprise outcomes", Journal of Safety Research, Vol. 71, pp. 259-271.

Kurdve, M., Zackrisson, M., Wiktorsson, M. \& Harlin, U. (2014), "Lean and green integration into production system models - experiences from Swedish industry", Journal of Cleaner Production, Vol. 85, pp. 180-190.

Lenning, J. \& Gremyr, I. (2017), "Making internal audits business-relevant", Total Quality Management \& Business Excellence, Vol. 28 Nos 9-10, pp. 1106-1121.

Massoud, M. A., Fayad, R., El-Fadel, M. \& Kamleh, R. (2010), "Drivers, barriers and incentives to implementing environmental management systems in the food industry: A case of Lebanon", Journal of Cleaner Production, Vol. 18 No.3 , pp. 200-209.

Morse, J. M. (1994), "Designing funded qualitative research', in Denzin, N.K. and Lincoln, Y.S. (Eds.): Handbook of qualitative research", 2nd ed., pp. 220-235, Sage Publications, Thousand Oaks, CA.

Muralikrishna, I. V. \& Manickam, V. (2017), ISO 9000, 14000 Series, and OHSAS 18001, in Muralikrishna, I. V. \& Manickam, V. (Ed.s), Environmental Management: Science and Engineering for Industry, Oxford publishing, United Kingdom, pp. 177-208.

Muraliraj, J., Zailani, S., Kuppusamy, S., \& Santha, C. (2018), "Annotated methodological review of Lean Six Sigma", International Journal of Lean Six Sigma, Vol. 9 No. 1, pp. 2-49.

Murugaiah, U., Jebaraj, B, S., Srikamaladevi, M, M. \& Muthaiyah, S. (2010), "Scrap loss reduction using the 5-whys analysis", International Journal of Quality \& Reliability Management, Vol. 27 No. 5, pp. 527-540.

Nguyen, Q. A. \& Hens, L. (2015), "Environmental performance of the cement industry in Vietnam: the influence of ISO 14001 certification", Journal of Cleaner Production, Vol. 96, pp. 362-378.

Oliveira, Sá, J. C. \& Fernandes, A. (2017), "Continuous improvement through "Lean Tools": An application in a mechanical company", Proceedings of Manufacturing Engineering Society International Conference, Vol. 13, pp. 1082-1089.

Oliveira \& Serra Pinheiro, C. R. M. (2009), "Best practices for the implantation of ISO 14001 norms: a study of change management in two industrial companies in the Midwest region of the state of São Paulo - Brazil", Journal of Cleaner Production, Vol. 17 No.9, pp. 883-885.

Pampanelli, A. B., Found, P., \& Bernardes, A. M. (2014), "A Lean \& Green Model for a production cell", Journal of Cleaner Production, Vol. 85, pp. 19-30.

Parmar, P. S., \& Desai, T. N. (2019), "A systematic literature review on Sustainable Lean Six Sigma", International Journal of Lean Six Sigma, Vol. 11 No. 3, pp. 429-461.

Patton, M. Q. (2002). Qualitative evaluation and research methods, 3rd ed., Sage Publications, Inc, Newbury Park, CA.

Persis, D. J., S, A., Sunder M, V., G, R., Sreedharan, V. R., \& Saikouk, T. (2020), "Improving patient care at a multi-speciality hospital using lean six sigma", Production Planning \& Control, pp. $1-19$.

Powell, D., Lundeby, S., Chabada, L. \& Dreyer, H. (2017), "Lean Six Sigma and environmental sustainability: the case of a Norwegian dairy producer", International Journal of Lean Six Sigma, Vol. 8 No.1, pp. 53-64. 
Puvanasvaran, P., Swee Tian, R. K. \& Vasu, S. A. L. (2014), "Lean environmental management integration system for sustainability of ISO 14001:2004 standard implementation" Journal of Industrial Engineering and Management, Vol. 7 No. 5, pp. 1124-1144.

Roy, P., Orikasa, T., Thammawong, M., Nakamura, N., Xu, Q. \& Shiina, T. (2012), "Life cycle of meats: An opportunity to abate the greenhouse gas emission from meat industry in Japan", Journal of Environmental Management, Vol. 93 No. 1, pp. 218-224.

Saad, N., Al-Ashaab, A., Maksimovic, M., Zhu, L., Shehab, E., Ewers, P. \& Kassam, A. (2013), “A3 thinking approach to support knowledge-driven design", The International Journal of Advanced Manufacturing Technology, Vol. 68 Nos 1-4, pp. 1371-1386.

Salleh, N. A. M., Kasolang, S., Jaffar, A. \& Halim, N. H. A. (2015), "Lean TQM leadership management practices in malaysian automotive companies", Jurnal Teknologi, Vol. 70 No. 6, pp. 1-6.

Sartal, A., Martinez-Senra, A. I., \& Cruz-Machado, V. (2018), "Are all lean principles equally ecofriendly? A panel data study", Journal of Cleaner Production, Vol. 177, pp. 362-370.

Sartor, M., Orzes, G., Touboulic, A., Culot, G. \& Nassimbeni, G. (2019), "ISO 14001 standard: Literature review and theory-based research agenda", Quality Management Journal, Vol. 26 No. 1, pp. 32-64.

Simons, D. \& Zokaei, K. (2005), "Application of lean paradigm in red meat processing", British Food Journal, Vol. 107 No. 4, pp. 192-211.

Sorooshian, S., \& Ting, K. C. (2018), "Reasons for implementing ISO 14001 in Malaysia", Environmental Quality Management, Vol. 27 No. 4, pp. 125-133.

Souza, J. P. E. \& Alves, J. M. (2018), "Lean-integrated management system: A model for sustainability improvement", Journal of Cleaner Production, Vol. 172, pp. 2667-2682.

Tavallaei, M. \& Talib, M. A. (2010), "A General Perspective on Role of Theory in Qualitative Research", Journal of International Social Research, Vol. 3, pp. 570-577.

Testa, F., Rizzi, F., Daddi, T., Gusmerotti, N. M., Frey, M. \& Iraldo, F. (2014), "EMAS and ISO 14001: the differences in effectively improving environmental performance", Journal of Cleaner Production, Vol. 68, pp. 165-173.

Tortorella, Cauchick-Miguel, P. A. \& Gaiardelli, P. (2019), "Hoshin Kanri and A3: a proposal for integrating variability into the policy deployment process", The TQM Journal, Vol. 31 No.2, pp. 118-135.

Verrier, B., Rose, B., Caillaud, E. \& Remita, H. (2014), "Combining organizational performance with sustainable development issues: the Lean and Green project benchmarking repository", Journal of Cleaner Production, Vol. 85 No. 1, pp. 83-93.

Womack, J.P, Jones, D. T. \& Roos, D. (2007), The Machine That Changed the World: The Story of Lean Production-Toyota's Secret Weapon in the Global Car Wars That is Now Revolutionizing World Industry, Simon and Schuster, New York, NY. U.S.A

Yin, R.K. (2014), Case Study Research: Design and Methods, 5 ${ }^{\text {th }}$ ed., Sage publications, Thousand Oaks, CA.

Wong, J. J., Abdullah, M. O., Baini, R. \& Tan, Y. H. (2017), "Performance monitoring: A study on ISO 14001 certified power plant in Malaysia", Journal of Cleaner Production, Vol. 147, pp. 165174.

Zsidisin, G. A., Melnyk, S. A., \& Ragatz, G. L. (2005), "An institutional theory perspective of business continuity planning for purchasing and supply management", International Journal of Production Research, Vol.43 No. 16, pp. 3401-3420.

Zokaei, K. \& Simons, D. (2006), "Performance improvements through implementation of lean practices: A study of the U.K. Red Meat Industry", International Food and Agribusiness Management Review, Vol. 9 No. 2, pp. 30-52. 


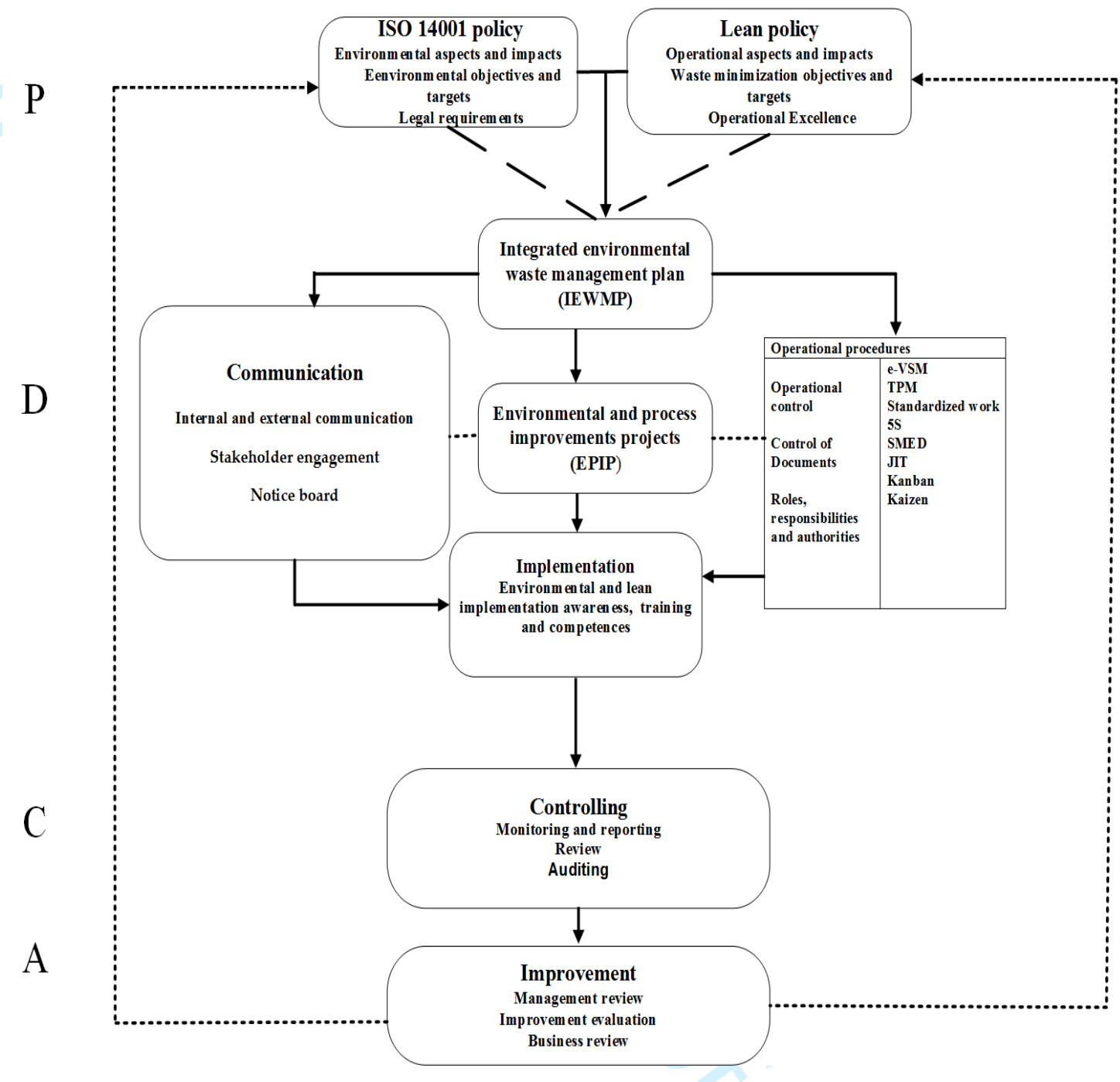

Figure 1. Integrated conceptual framework for lean and ISO 14001 implementation, sourced from Ahmed and Mathrani (2019). 


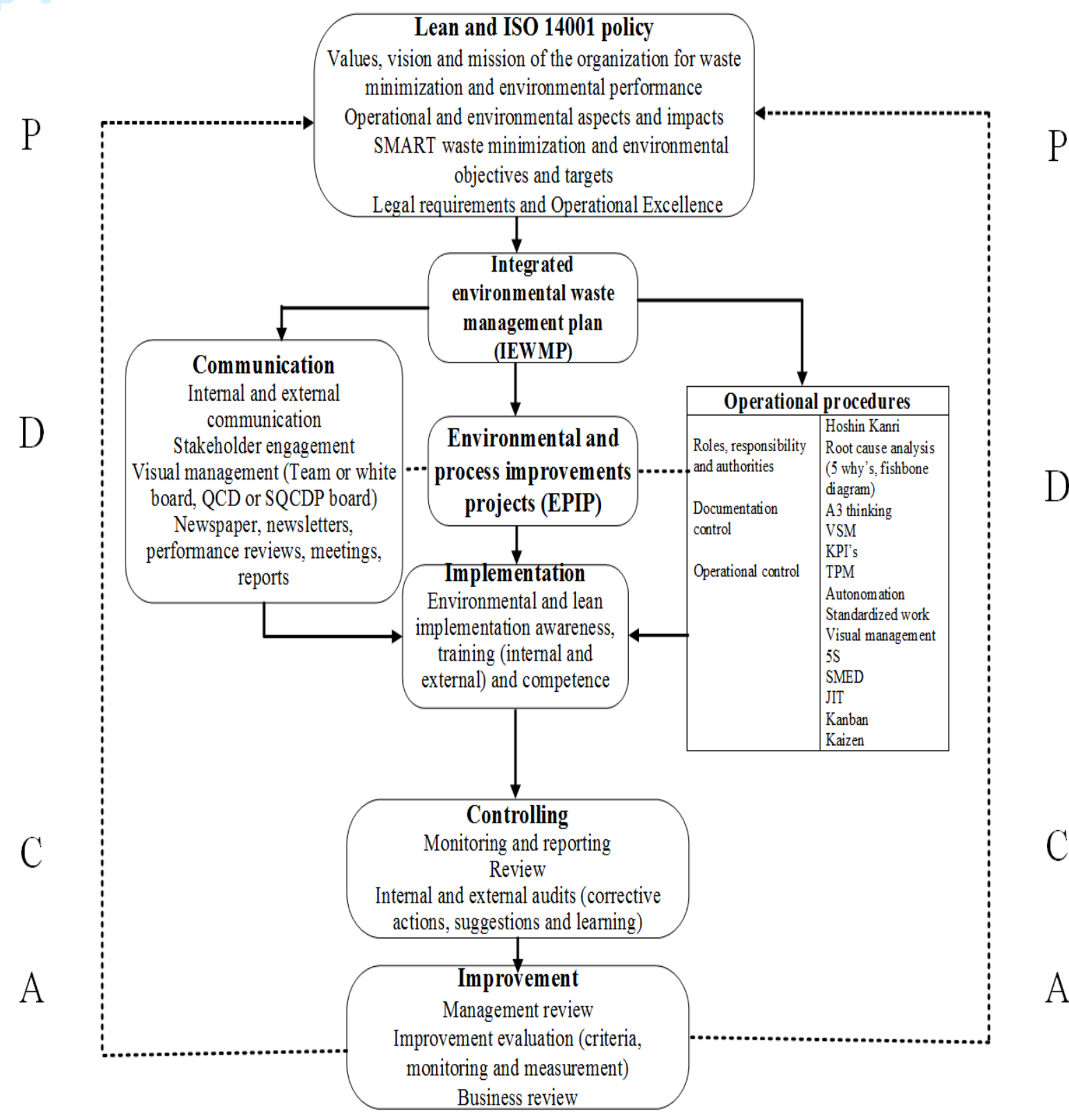

Figure 2. Revised conceptual framework for an integrated lean and ISO 14001 implementation 
Table I. Profiles of the informants interviewed

Description

\begin{tabular}{ll}
\hline Lean-ISO1 & $\begin{array}{l}\text { A managing director who has 10 years of experience in both lean and ISO 14001 domains in the meat } \\
\text { industry }\end{array}$ \\
\hline Lean-ISO2 & $\begin{array}{l}\text { A managing director who has } 6 \text { years of experience in both lean and ISO 14001 domains in the meat } \\
\text { industry }\end{array}$ \\
\hline Lean-1 & $\begin{array}{l}\text { A director and a senior consultant having 11 years of experience in lean implementation in the meat } \\
\text { industry }\end{array}$ \\
\hline Lean-2 & A managing director who has 18 years of experience in lean implementation in the meat industry \\
\hline ISO-1 & A health and safety manager with 8 years of experience in the meat industry \\
\hline ISO-2 & A technical manager on management systems with 10 years of experience in the meat industry \\
\hline
\end{tabular}


Table II. A combined approach of lean tools and ISO 14001 procedures for environmental performance

\begin{tabular}{lll}
\hline Process aspects & Lean tools and references & ISO 14001 procedures and references \\
\hline $\begin{array}{l}\text { Identification of environmental } \\
\text { problems for setting targets }\end{array}$ & $\begin{array}{l}\text { Root cause analysis (5-whys) and } \\
\text { fishbone diagram (Ashok } \text { et al. (2013)) }\end{array}$ & $\begin{array}{l}\text { Framework for setting environmental objectives, } \\
\text { compliance and continuous improvement (Souza } \\
\text { and Alves (2018) and Kruse } \text { et al. (2019)) }\end{array}$ \\
\hline $\begin{array}{l}\text { Identification of process non- } \\
\text { conformities and improvement } \\
\text { program }\end{array}$ & $\begin{array}{l}\text { Root cause analysis (5-whys) and other } \\
\text { lean tools (Ashok } \text { et al. (2013) and } \\
\text { Gangidi (2013)) }\end{array}$ & $\begin{array}{l}\text { Process non-conformance identification and } \\
\text { competences training program (Souza and Alves } \\
\text { (2018) and Kruse } \text { et al. (2019)) }\end{array}$ \\
\hline Communication & $\begin{array}{l}\text { Visual management (SQCDP board) } \\
\text { (Bateman et al. (2016) and Eaidgah } \text { et }\end{array}$ & $\begin{array}{l}\text { Internal and external communication for } \\
\text { effectiveness of EMS (Souza and Alves (2018)) }\end{array}$ \\
\hline $\begin{array}{l}\text { al. (2016)) } \\
\text { identification of environmental } \\
\text { with stakeholders }\end{array}$ & $\begin{array}{l}\text { A3 thinking (Saad } \text { et al. (2013) and } \\
\text { Souza and Alves (2018)), 5S (Souza } \\
\text { and Alves (2018)) }\end{array}$ & $\begin{array}{l}\text { Communication with stakeholders for evaluation } \\
\text { of issues and solutions (Souza and Alves (2018) } \\
\text { and Kruse } \text { et al. (2019)) }\end{array}$ \\
\hline Audit of processes & 5S audit (Gupta and Jain (2013)) & $\begin{array}{l}\text { Environmental performance monitoring (internal } \\
\text { audit) (Souza and Alves (2018), Abdullah } \text { et al. } \\
\text { (2018)) }\end{array}$ \\
\hline $\begin{array}{l}\text { Monitoring and performance } \\
\text { evaluation }\end{array}$ & $\begin{array}{l}\text { Visual management (SQCDP board) } \\
\text { and VSM (Eaidgah } \text { et al. (2016)) }\end{array}$ & $\begin{array}{l}\text { Performance evaluation for improvement (Souza } \\
\text { and Alves (2018) and Kruse } \text { et al. (2019)) }\end{array}$ \\
\hline Documentation of processes & Visual management and VSM (Souza \\
and Alves (2018)) & $\begin{array}{l}\text { Process support (document control) (Souza and } \\
\text { Alves (2018)) }\end{array}$ \\
\hline
\end{tabular}


An integrated lean and ISO 14001 framework for environmental performance: an assessment of New Zealand meat industry

\author{
Ahmed, A
}

$2021-10-28$

22/04/2023 - Downloaded from MASSEY RESEARCH ONLINE 